\title{
Diversity of metaxylem vessel elements in three Syagrus palms (Arecaceae) of different habits
}

\author{
Marcelo Rodrigo Pace ${ }^{1,2,3}$, Marli Pereira Botânico ${ }^{1}$ and Veronica Angyalossy ${ }^{1}$
}

Recebido em 27/09/2010. Aceito em 18/03/2011

\begin{abstract}
RESUMO
(Diversidade dos elementos de vaso do metaxilema em três espécies de Syagrus (Arecaceae) de diferentes hábitos). Elementos de vasos em monocotiledôneas apresentam diferenças morfológicas de acordo com o órgão onde ocorrem. Tais diferenças têm sido explicadas sobretudo de um ponto de vista evolutivo, com poucos dados acerca de como a função de um órgão ou o hábito de crescimento de uma planta influenciariam na morfologia dos elementos de vaso. Para responder tal pergunta, foram analisados os órgãos vegetativos de três palmeiras do mesmo gênero, Syagrus, crescendo em ambientes similares, mas com hábitos diferentes. Assim, buscamos detectar se os elementos de vaso apresentariam características similares em todas as espécies ou se mudariam de acordo com os diferentes hábitos. Tanto a largura quanto o tipo de placa de perfuração variaram de maneira semelhante em todas as espécies, ao passo que os comprimentos variaram de uma forma inédita. Primeiramente, todas as espécies apresentaram elementos de vaso nas raízes tão ou mais longos que aqueles dos caules e folhas. Além disso, os elementos de vaso dos caules variaram consideravelmente entre as espécies. Especificamente, em Syagrus romanzoffiana os elementos de vaso apresentaram igual comprimento em todos os órgãos, enquanto tanto Syagrus flexuosa quanto Syagrus petraea, vaso mais curtos foram encontrados nos caules. Provavelmente os elementos de vaso das raízes de palmeiras estão envolvidos na criação de altos potenciais hídricos necessários para evitar embolia no caule. O dimorfismo dos vasos no caule possivelmente reflete os hábitos diferentes destas espécies. Caules de maiores dimensões, como os de palmeiras arbóreas, apresentam elementos de vaso mais longos que aqueles de caules subterrâneos. Com base nos resultados anatômicos aqui expostos, sugerimos que as diferenças encontradas nos elementos de vaso da raiz, caule e folha teriam evoluído não só devido a pressões filogenéticas e ecológicas, mas também devido a especificidades inerentes aos diferentes hábitos de crescimento presentes nas plantas.
\end{abstract}

Palavras-chave: Monocotiledôneas, elementos traqueais, órgãos vegetativos, hábitos de crescimento, raiz, caule, folha

\begin{abstract}
(Diversity of metaxylem vessel elements in three Syagrus palms (Arecaceae) of different habits). Vessel elements in Monocotyledons present morphological differences according to the organ where they occur. Usually such differences have been explained from an evolutionary perspective, with few data on how the vessel elements could be influenced by the different functions of organs and the growth habits of the plants. To address this question, three vegetative organs of palms of the same genus, Syagrus, growing in similar environments, but with different habits, were analyzed. Accordingly, we aimed to detect whether the vessel elements would present similar features in all species or whether the vessel elements would change according to their different habits. We found that the width and type of perforation plates varied in the same way among all species, while the lengths varied in an unusual form. First, all species presented very long elements in the roots, either as long, or longer than those of the stems and leaves. Second, the vessel elements of the stems varied considerably among the species. Specifically, in Syagrus romanzoffiana, vessel elements of the stem were equal in size to those of the other organs, while in both Syagrus flexuosa and Syagrus petraea, shorter vessel elements were found in the stems. We surmise that vessel elements in palm roots may be related to the high pressure-potential required to avoid stem embolism. The dimorphism of the vessel elements in the stems most likely reflects the distinct habits of these species. Large stems, such as of those of the arboreal palms, presented much longer vessels than those of subterranean stems. Based on these anatomical findings, we suggest that the differences found among the vessel elements of roots, stem, and leaves may have evolved in response not only to phylogenetic and ecological constraints, but also to specificities derived from the different plant habits.
\end{abstract}

Key words: Monocotyledons, tracheary elements, vegetative organs, growth habit, root, stem, leaf

\footnotetext{
Universidade de São Paulo, Instituto de Biociências, Departamento de Botânica, Laboratório de Anatomia Vegetal. São Paulo, SP, Brazil

2 University of Helsinki, Department of Biological and Environmental Sciences and Institute of Biotechnology, Helsinki, Finland

3 Author for correspondence: marcelorpace@yahoo.com.br
} 


\section{Introduction}

Vessel elements in Monocotyledons are known to present marked morphological differences among distinct organs of the same plants. Such differences include length, width and perforation plates. This diversity, in turn, has been directly correlated to the origin and specialization of vessel elements across the different organs of the Monocotyledons. Since vessel elements are thought to have evolved from tracheids, vessels with features similar to them would be regarded as the most primitive, while those with the most dissimilar features would be regarded as the most advanced (Bailey \& Tupper 1918; Frost 1930a; b; Bailey 1944). Continuing this logic, these authors further suggested that vessels that are long and narrow with multi-perforated plates would be considered the most primitive and less specialized, while short, wide and simple perforated vessels would be considered both the most advanced and specialized. In a series of studies, Cheadle (1942; 1943a; b; 1944; 1953) described the characteristics of the tracheary elements in a sample of over 300 species belonging to more than 200 genera from most Monocot families and found root vessels to be more specialized than those of either stems or leaves. Accordingly, root vessels would display short, wide and simple perforated plates, while the leaves would present long, narrow and multi-perforated plates. Stems would present intermediate features between roots and leaves. These nearly consistent differences seen in the Monocot organs led Cheadle (1943a; b) to infer that the vessel elements in Monocotyledons would have first appeared in the roots, then at the stems and finally in the leaves. This presumption was supported by the fact that some Monocotyledons would present vessels only in the roots (Cheadle 1943a; b), and in these cases, such vessels would display less specialized features.

Born in a gradist context, the order of specialization first proposed by Bailey \& Tupper (1918), and later reinforced by Cheadle (1943a; b), finally found support in cladistic studies (Carlquist \& Schneider 2002) and in a number of studies with the Monocotyledons (Carlquist 1975; Parthasarathy \& Klotz 1976; Klotz 1978a; b; Carlquist \& Schneider 1997; 1998a; b; 2006; 2007; Schneider \& Carlquist 1997; 1998; 2005). The long series of studies by Carlquist \& Schneider (cited above) showed, moreover, that in some families not possessing vessels in stems or leaves, as recorded by Cheadle (1942), vessels would otherwise be present, but with perforations only recognizable through scanning electron microscopy (SEM). The reason their perforations were only visible by SEM came from the fact that these perforations possess many pit membrane remnants, a phenomenon interpreted as an indicator of an intermediate stage of perforation plate formation in these plants. Pit membrane remnants were also seen in basal Angiosperms (Schneider \& Carlquist 1995; 1996) and ferns (Schneider \& Carlquist 2000a; b; Carlquist \& Schneider 2001; 2007). These findings support the idea that the perforation plates would have evolved from the dissolution of the pit membranes in the pit fields, as previously proposed by Bailey \& Tupper (1918) and Bailey (1944), and that their presence would indicate an intermediate stage of specialization.

Regarding ecological factors, Cheadle and Whitford (1941) and Cheadle (1943a; b) asserted that the differences among vessel elements across the plant organs are relatively independent of the environment. This is an opinion, however, not entirely shared by Carlquist (1975), who suggested that the Monocotyledons with the most primitive features would actually be growing in aquatic or mesic environments, while those with more advanced features would grow in seasonal environments with a marked dry season. This suggestion was further supported both by ecological and experimental studies, which illustrate that the vessel elements tend to show convergences independent of their phylogenetic relationships for plants growing in similar environments (Maherali et al. 2004). For instance, vessel elements tend to reduce in size from mesic to xeric environments (Baas et al. 1983). In addition to convergences, reversions have also been found within many groups, such as Aquifoliaceae in the Eudicots, showing that the so-called "primitive features" may sometimes be selected over "advanced features" (Sperry et al. 2007). In such cases, the morphology of vessel elements is related to both the efficiency of water conduction and protection in the event of embolism (Carlquist 1975; Baas et al.1983), as well as phylogenetic influences. That is, while the so-called less specialized vessel elements, with long, narrow and multi-perforated plates, are considered less efficient for water conduction, they are, at the same time, more protective against embolism since they are more easily refilled when embolism happens (Canny 2001; Sperry 2003).

Other factors also seem to affect the morphology of vessel elements, namely, the function of a given organ and the growth habit of a plant. Storage organs such as rhizomes, for example, were shown either not to possess vessels or to possess vessel elements with more primitive features (Cheadle 1942; Carlquist \& Schneider 2006). The presence of less specialized vessel elements was related to the apparent slow rate of conduction presented to these organs (Carlquist \& Schneider 2006). In terms of growth habit, vessel elements of monocot vines are known to be the widest vessels among the Monocotyledons (Klotz 1978a; b; Tomlinson et al. 2001; Fisher et al. 2002), even though different genera may present different perforation plate types, either simple or multiple (Klotz 1978a; b), thus rebutting a direct correlation between growth habit and level of specialization. Hence, in spite of the clear correlation between the form of vessel elements and the environment, how plant habit might influence the morphology of vessel elements remains elusive. One way to address this question would be to examine the morphology of vessel elements in closely related taxa growing in similar environments, but with different habits.

In the present study, we therefore analyzed three palms of the same genus, Syagrus, growing in similar environ- 
ments, but with fairly different habits. Using this approach, we aimed to detect whether the vessel elements would present similar features in all species, given the taxonomic proximity of these species, or whether the vessel elements would change according to the different growth habits.

\section{Material and methods}

Three species of Syagrus (Arecoideae, Cocoseae; Dransfield et al. 2005) displaying three different growth habits were sampled in their natural habitats (Table 1). The genus Syagrus is neotropical and widely distributed, presenting a considerable range of habits. Here, a singlestemmed solitary palm, a caespitose suckering palm and a palm with underground stem were studied (Table 1). Moreover, at least three individuals of each species were entirely collected (Table 1), and they were all growing in environments marked with seasonal water stress periods. In fact, both the Restingas of São Paulo (forest formations between the dunes and the rainforest) and the Cerrado (Neotropical savannas) possess alternating wet and dry seasons. Our idea was to reduce phylogenetic and environmental variables to the extent possible in order to test exclusively the influence of the growth habits in vessel element morphologies.

All specimens were immediately fixed in FAA $70(10 \%$ formalin, 5\% acetic acid, 70\% ethanol; Berlyn \& Mikshe 1976) and then stored in 70\% ethanol. Analyses were made from roots, stems and leaves. Both roots and stems were sectioned in a sliding microtome. The roots and stem of Syagrus petraea had their entire circumference crosssectioned, while the remaining stems were too wide and were therefore cut from cubic samples of $4 \mathrm{~cm}^{3}$. Finally, for the leaves, we made free-hand sections of the midrib and adjacent leaf blade. Sectioning palm organs can be extremely challenging, since they possess very hard vascular tissues embedded in a matrix of parenchyma. To mitigate this problem, small sections of the roots, stem, and mid portion of the leaves were softened in 10\% ethylenediamine for up to four days (Carlquist 1982) within a hot chamber at $58^{\circ}$ C. Samples were then gradually embedded in increasingly concentrated solutions of polyethylene glycol 1500 starting at $10 \%$ and $20 \%$, until a $100 \%$ polyethylene glycol medium was obtained, allowing one day at each concentration (Rupp 1964, modified). Samples were subsequently sectioned with the help of anti-tearing resins made of an expanded polystyrene (foam) solution applied upon the stem before sectioning in a sliding microtome (Barbosa et al. 2010). Sections were double-stained in Astra Blue-Safranine 9:1 in 50\% ethanol, a modification of Bukatsch (1972), and mounted in Canada Balsam to make permanent slides. Observation of vessel elements also required the organs to be macerated in a solution of 50\% Acetic Acid and 50\% Hydrogen Peroxide overnight (Franklin 1945), with subsequent staining in 1\% Safranine and $50 \%$ ethanol and mounted in semi-permanent slides with glycerin.

At least 50 slides with macerated material were mounted per organ per specimen, and all the quantitative data on length and width were obtained using the Zeiss KS 100 software. Deciding how many vessel elements would be measured per organ per species was made possible by applying the equation for sample size proposed by Eckblad (1991). According to this analysis, 30 vessel elements per organ per species were shown to be a reasonable number to sample. Subsequently, t-tests were performed to investigate whether the means for the length and width of vessel elements were statistically different in the distinct organs. In addition, it should be noted that only metaxylem vessels were analyzed. To assure that we were analyzing metaxylem vessels, we considered exclusively those vessels that had bordered pits, since protoxylem vessels were either tracheids or vessels with helical and/or annular thickening.

For qualitative analysis, the diversity in vessel element morphology was captured both in the anatomical crosssectioned samples and in the macerations. Such diversity was registered in line drawings produced with the aid of a camera lucida.

\section{Results}

\section{Vascular Anatomy}

Proper identification of the distributional pattern of vessel elements in the vascular system of different plant organs depends on anatomical analysis; therefore, a brief description is given for each organ.

All roots collected in Syagrus are stem borne (adventitious) (Fig. 1A). Their vascular system is formed by protoxylem poles radially followed by metaxylem vessel elements, in alternation with primary phloem (Fig. 1A). Considering the tracheary elements, the increase in width from the protoxylem to the metaxylem is evident, with the

Table 1. List of studied species and collection details. ${ }^{*}$

\begin{tabular}{lcccc}
\hline Species & Collector Number & Growth habits & Environment \\
\hline Syagrus romanzoffiana (Chamisso) Glassman & Botânico 12, 13, 14 & Solitary palm, arboreal & Restinga - Jureia - State of São Paulo \\
Syagrus flexuosa (Mart.) Becc. & Botânico 9, 10, 11 & Caespitose suckering palm & Cerrado - Mogi-Guaçu - State of São Paulo & Cerrado - Itirapina - State of São Paulo \\
\hline Syagrus petraea (Mart.) Becc. & Botânico 20, 21, 22 & Palm with underground stem & .
\end{tabular}

*All species possess voucher in the SPF herbarium. 
late metaxylem vessels being the widest vessels in the roots. There are as many as 20 protoxylem poles. Moreover, when the root is more mature, it can be observed that a great part of the parenchyma becomes sclerified and surrounds all the conducting cells (Fig. 1A).

The stems are marked by the presence of vascular bundles and fiber strands scattered in a matrix of parenchyma (Fig. 1B), with two distinct types of vascular bundles detected, some with proto- and metaxylem and others with metaxylem alone (Fig. 1B). In addition to the tracheary elements, the vascular bundles are also composed of primary phloem surrounded by a wide and thick cap of fibers (Fig. 1E).

The leaves of Syagrus possess reduplicate leaf segments with the midrib presenting a central vascular system composed of one large bundle with proto- and metaxylem associated with several primary phloem strands and additional vascular bundles on the sides possessing only metaxylem, the latter juxtapositioned with primary phloem (Fig. 1C). Such vascular system is surrounded by a sheath of fibers (Fig. 1C). All other bundles in the leaf blade are smaller and present proto- and metaxylem vessels associated with primary phloem, either totally or partially surrounded by a sheath of fibers (Fig. 1F). In our analyses, we preferentially sampled vessels from the central vascular system of the midrib.

\section{Dimorphism of Vessel Elements}

All the numerical values for metaxylem vessel elements can be found in Table 2. Moreover, the diversity of vessel elements, as found in root, stem, and leaves, is presented in Figure 2 in the form of line drawn pictures. It should be noted, however, that Figure 2 shows the diversity of vessel elements found across all organs, not the most abundant vessel element types present. A detailed description of vessel element morphology is provided below.

\section{Perforation plate}

The perforation plates show an identical pattern in all three Syagrus species. In the roots, there was a predominance of simple and transverse perforation plates (Fig. 1G), with only a few vessels presenting slightly inclined perforation plates with few bars (up to 5; Fig. 2A, D, G). Although some elements presented simple plates in the stems, practically all vessels presented slightly inclined perforation plates with few bars (from 2 to 7 ) in at least one extremity of the vessel elements (Fig. 1H, 2B, E, H), while on the leaves, all vessels presented inclined perforation plates with many bars (Fig. 1I, 2C, F, I), usually more than twenty.

\section{Width}

The widths of the vessel elements were consistent in all species studied. The vessels in the roots were always the widest (Fig. 1D, 2), with means ranging from 167-272 mm, while the vessels in the leaves presented the narrowest diameters (Fig. 1F, 2), with means ranging from $30-50 \mathrm{~mm}$. The vessels in the stems were intermediate (Fig. 1E, 2), ranging from 60-130 $\mathrm{mm}$. These results indicate a decrease in width from the root to the leaves, something corroborated by statistical analysis with $\mathrm{P}<0.05$.

\section{Length}

Contrary to the quantitative consistency in perforation plates and width, much more variability was identified in the lengths of vessel elements in the three Syagrus species studied (Table 2, Fig. 2). For Syagrus romanzoffiana, all vessels presented similar lengths, from approximately $1300-$ $1700 \mathrm{~mm}(\mathrm{P}>0.05)$, while for Syagrus flexuosa and Syagrus petraea, the stem vessel elements were significantly shorter than those of the root and leaves $(\mathrm{P}<0.05)$. In fact, Syagrus flexuosa presents roots and leaves with vessel elements of similar means $(P>0.05)$, ranging from $1100-1600 \mathrm{~mm}$, while the stems possess a considerably different mean (for Syagrus flexuosa: $940 \mathrm{~mm} ; \mathrm{P}<0.05$ ). For Syagrus petraea, the differences were even more pronounced, with stem vessels having less than a third of the length of either root or leaf vessel elements (mean $300 \mathrm{~mm}$ ).

\section{Vascular parenchyma}

\section{Paratracheal contact parenchyma tissue}

Parenchyma was found closely associated with the vessel elements in all species examined (Fig. 3A-B). These contact parenchyma cells are rectangular in shape (Fig. 3B$\mathrm{C})$ and present simple to semi-bordered scalariform pits in contact with the vessel elements (Fig. 3B-C). Moreover, they are so intimately associated with the vessel elements that it is possible to see their shape impressed on the vessels even in longitudinal section (Fig. 3B) or in dissociated material (Fig. 3A).

\section{Discussion}

Our results confirm the results of previous investigations in that the vessel elements present marked differences between the organs of the Monocotyledons. Importantly, however, it also shows some newly discovered variations in the lengths of vessel elements among the organs. In fact, while the perforation plates and width presented exactly the same results previously reported for other Monocotyledons (Cheadle 1942; 1955; Cheadle \& Kosakai 1975), i.e., decrease in width and increase in the number of bars in the perforation plates from roots to leaves, we found two unusual patterns for Monocotyledons: i) very long vessel elements in the roots, as long or longer than those of the stems and leaves, and ii) variability in the length of vessel elements in stems. 

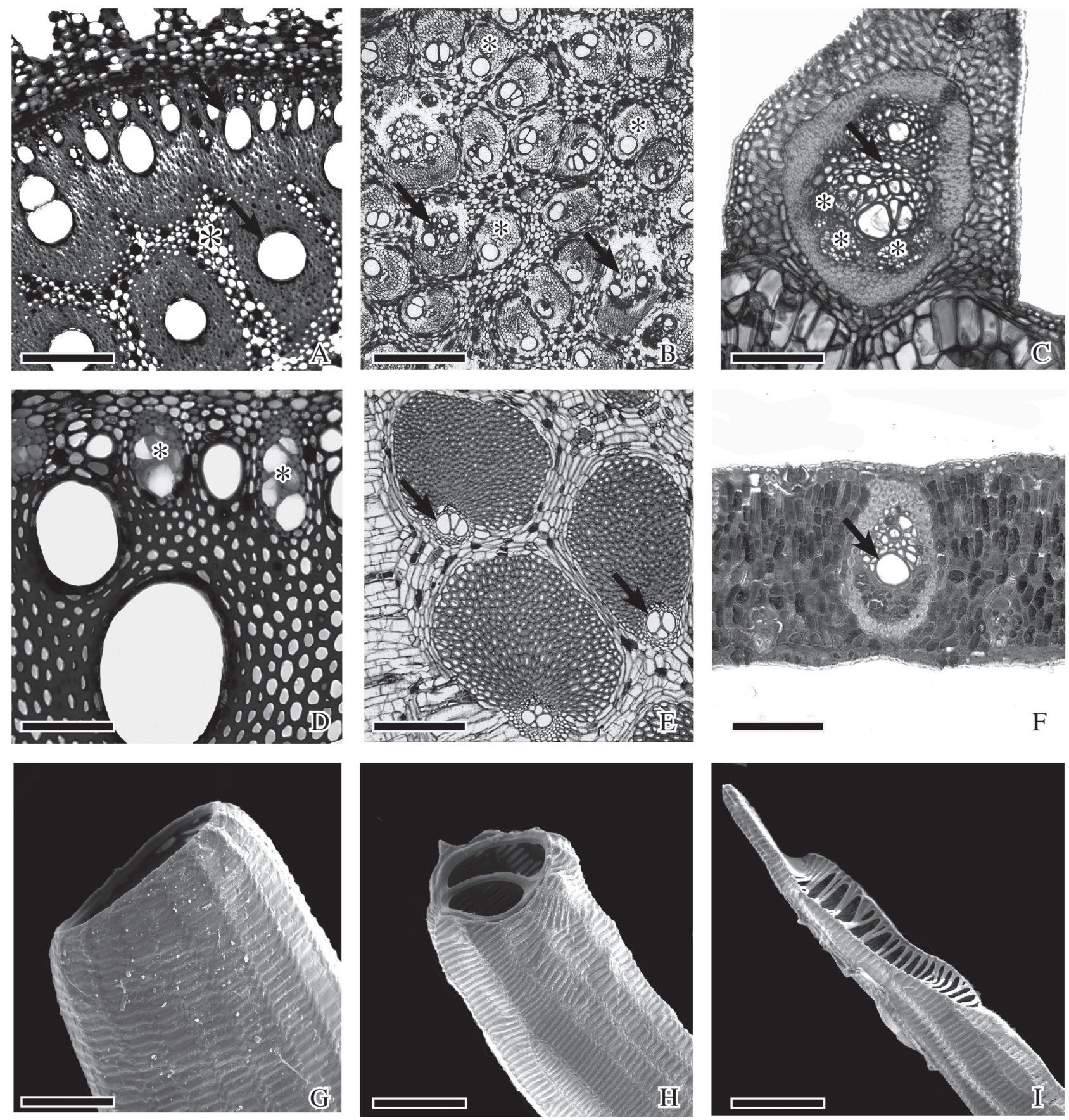

Figure 1. Vascular cylinder and vessel elements of Syagrus species. A. Syagrus petraea (Mart.) Becc., root transverse (TS) section showing vascular cylinder. Several protoxylem poles followed by metaxylem vessels (arrows). Sclerified parenchyma with some portions not sclerified (asterisk). B. Syagrus flexuosa (Mart.) Becc., stem (TS). Vascular bundles scattered in a matrix of parenchyma cells. Note bundles with proto- and metaxylem (arrows) and bundles with exclusively metaxylem vessels (asterisks). C. Syagrus petraea (Mart.) Becc., leaf-segment midrib (TS), showing a central vascular system with a robust bundle with protoxylem (arrow) and metaxylem associated with several phloem strands (asterisk) and an additional bundle upon it with exclusive metaxylem associated with a phloem strand (asterisk), each surrounded by a sheath of fibers. D. Syagrus flexuosa (Mart.) Becc., detail of a root (TS) showing protoxylem poles followed by metaxylem vessels in alternation with primary phloem (asterisks). E. Syagrus romanzoffiana (Cham.) Glassman, vascular bundles with metaxylem (arrows) juxtapositioned with primary phloem and a large cap of fibers. F. Syagrus flexuosa (Mart.) Becc., leaf blade (TS), showing a vascular bundle with proto and metaxylem (arrow), primary phloem and a sheath of fibers. G. Syagrus romanzoffiana (Cham.) Glassman, root vessel element with simple perforation plate. H. Syagrus flexuosa (Mart.) Becc., stem vessel element with multiple perforation plate with two bars. I. Syagrus petraea (Mart.) Becc., leaf vessel elements with multiple perforation plate with more than 20 bars. Scale bars: $A=500 \mu \mathrm{m}, \mathrm{B}=1.5 \mathrm{~mm}, \mathrm{C}$ and $\mathrm{F}=200 \mu \mathrm{m}, \mathrm{D}=300 \mu \mathrm{m}, \mathrm{E}=2 \mathrm{~mm}, \mathrm{G}=50 \mu \mathrm{m}, \mathrm{H}-\mathrm{I}=30 \mu \mathrm{m}$. 
ROOT

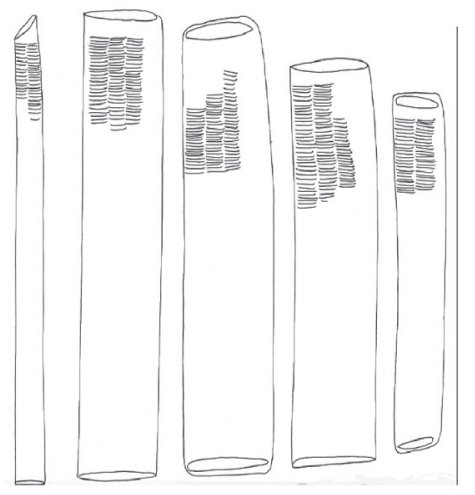

A

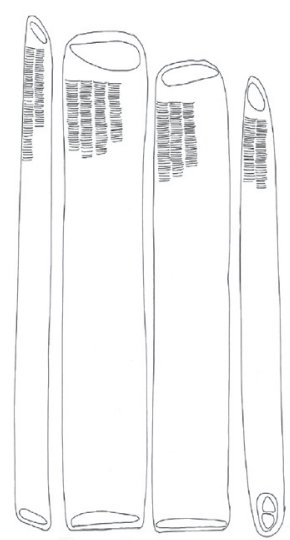

D

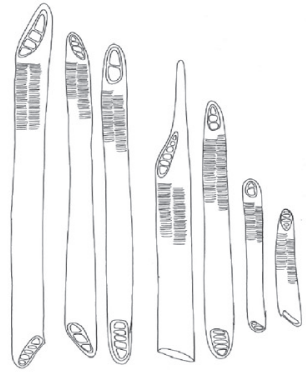

$\mathrm{E}$

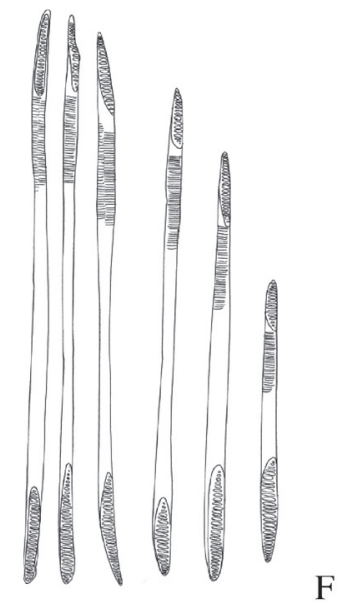

LEAF
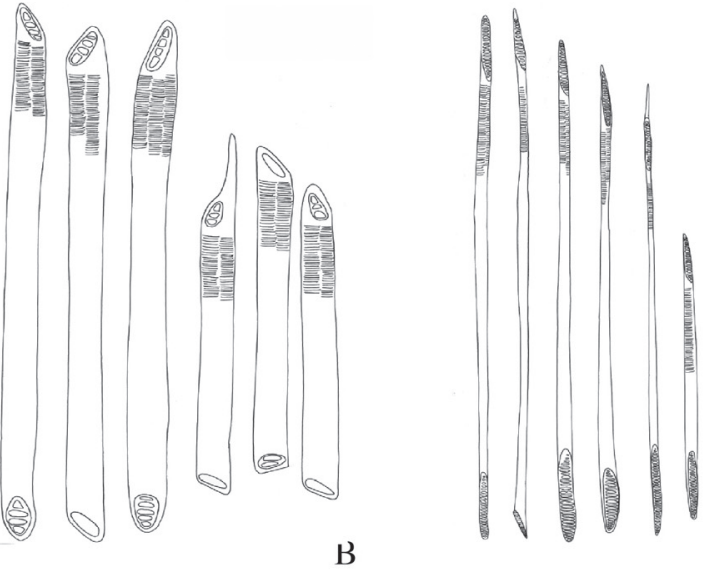

$\mathrm{C}$

F

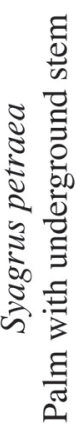
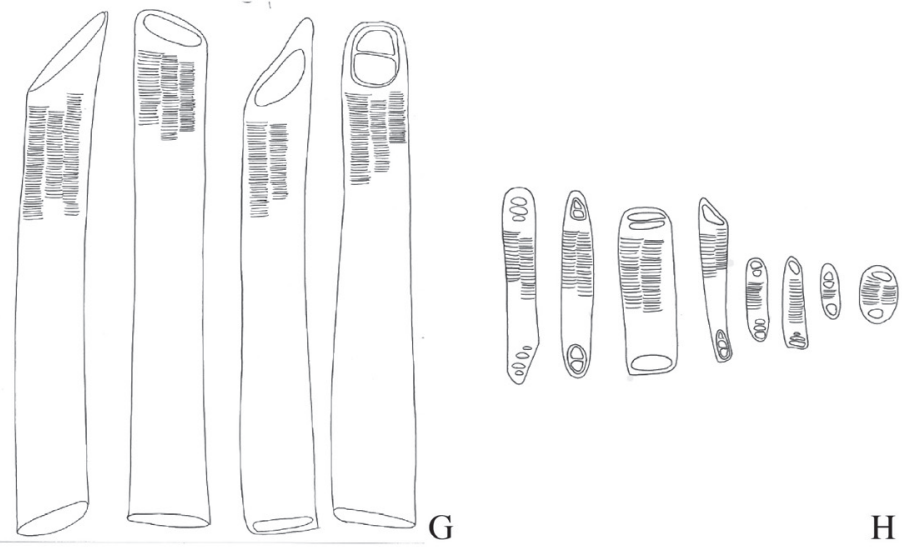

Figure 2. Morphological diversity of vessel elements across root, stem and leaves. A-C. Syagrus romanzoffiana (Cham.) Glassman. D-F. Syagrus flexuosa (Mart.) Becc. G-I. Syagrus petraea (Mart.) Becc. A, D, G. Very long root vessel elements with predominantly simple perforation plates. B, E, H. Stem vessel elements vary greatly in length among the species, but predominantly have multiple perforation plates with few bars. C, F, I. Leaf vessel elements are very long and narrow, with multiple perforation plates. Scale bar: $400 \mu \mathrm{m}$. 
Table 2. Numerical values for the vessel elements of the three Syagrus palms studied. Numbers represent means with their standard deviations aside.

\begin{tabular}{|c|c|c|c|c|c|c|c|c|c|}
\hline \multirow[t]{2}{*}{ Organ } & \multicolumn{3}{|c|}{ Syagrus romanzoffiana } & \multicolumn{3}{|c|}{ Syagrus flexuosa } & \multicolumn{3}{|c|}{ Syagrus petraea } \\
\hline & $\begin{array}{l}\text { Width } \\
(\mu \mathrm{m})\end{array}$ & Length $(\mu \mathrm{m})$ & Perforation plate & $\begin{array}{l}\text { Width } \\
(\mu \mathrm{m})\end{array}$ & $\begin{array}{l}\text { Length } \\
(\mu \mathrm{m})\end{array}$ & $\begin{array}{l}\text { Perforation } \\
\text { plate }\end{array}$ & $\begin{array}{l}\text { Width } \\
(\mu \mathrm{m})\end{array}$ & $\begin{array}{l}\text { Length } \\
(\mu \mathrm{m})\end{array}$ & Perforation plate \\
\hline Root & $272 \pm 63$ & $1366 \pm 283$ & Simple & $167 \pm 78$ & $1588 \pm 324$ & Simple & $242 \pm 51$ & $1596 \pm 232$ & Simple \\
\hline Stem & $132 \pm 29$ & $1464 \pm 584$ & $\begin{array}{l}\text { Compound } \\
\text { Less than } 5 \text { bars }\end{array}$ & $111 \pm 26$ & $940 \pm 243$ & $\begin{array}{l}\text { Compound } \\
\text { Less than } 5 \text { bars }\end{array}$ & $60 \pm 14$ & $309 \pm 100$ & $\begin{array}{l}\text { Compound Less } \\
\text { than } 5 \text { bars }\end{array}$ \\
\hline Leaves & $52 \pm 14$ & $1367 \pm 382$ & $\begin{array}{l}\text { Compound More } \\
\text { than } 10 \text { bars }\end{array}$ & $36 \pm 7$ & $1157 \pm 246$ & $\begin{array}{l}\text { Compound } \\
\text { More than } 10 \\
\text { bars }\end{array}$ & $32 \pm 6$ & $1408 \pm 335$ & $\begin{array}{c}\text { Compound More } \\
\text { than } 10 \text { bars }\end{array}$ \\
\hline
\end{tabular}

When analyzing the lengths of the vessel elements, phylogenetic, environmental and functional aspects must be considered. Phylogenetic aspects were discussed by Cheadle (1942) and Cheadle \& Kosakai (1975) who showed that the vessel elements tend to be more specialized in the roots and less specialized in the leaves. Similarly, within the idea that one group could have given rise to other groups, Cheadle (1955) showed that the families considered to be basal would coincidently be those possessing less specialized vessels across all organs, while the contrary would be true for those families thought to be derived. Here, contrary to what is known for other Monocotyledons, we found vessel elements in the roots to be as long, or longer, than the vessel elements found in the stem and leaves, a feature which, as noted previously, is considered to be more primitive, i.e., less specialized. Nonetheless, palms are within Arecales (Commelinids), one of the terminal branches in monocot's phylogeny (APG III 2009); thus, if Syagrus palms present long vessel elements in the roots, it contradicts the trends suggested by Cheadle.

Environmental or ecological features are also known to affect the form of vessel elements, with the length of vessel elements decreasing from mesic to xeric environments (Baas et al.1983). Nevertheless, the three Syagrus species analyzed here grow in a similar seasonal environment, i.e., alternating wet and dry seasons, and would be expected to have short rather than long vessels in the roots.

The answer for why the vessel elements in the roots are so long may be, then, in their functional role. Specifically, long vessels may permit the creation of high root pressure potentials (Davis 1961). High root pressure potentials are known to be effective in avoiding and repairing air embolisms. Moreover, since monocotyledonous stems also rely upon the same vessels throughout their lives (Sperry 1985), it can be expected that such a mechanism would be present to avoid embolism and stem tissue damage. High root pres-
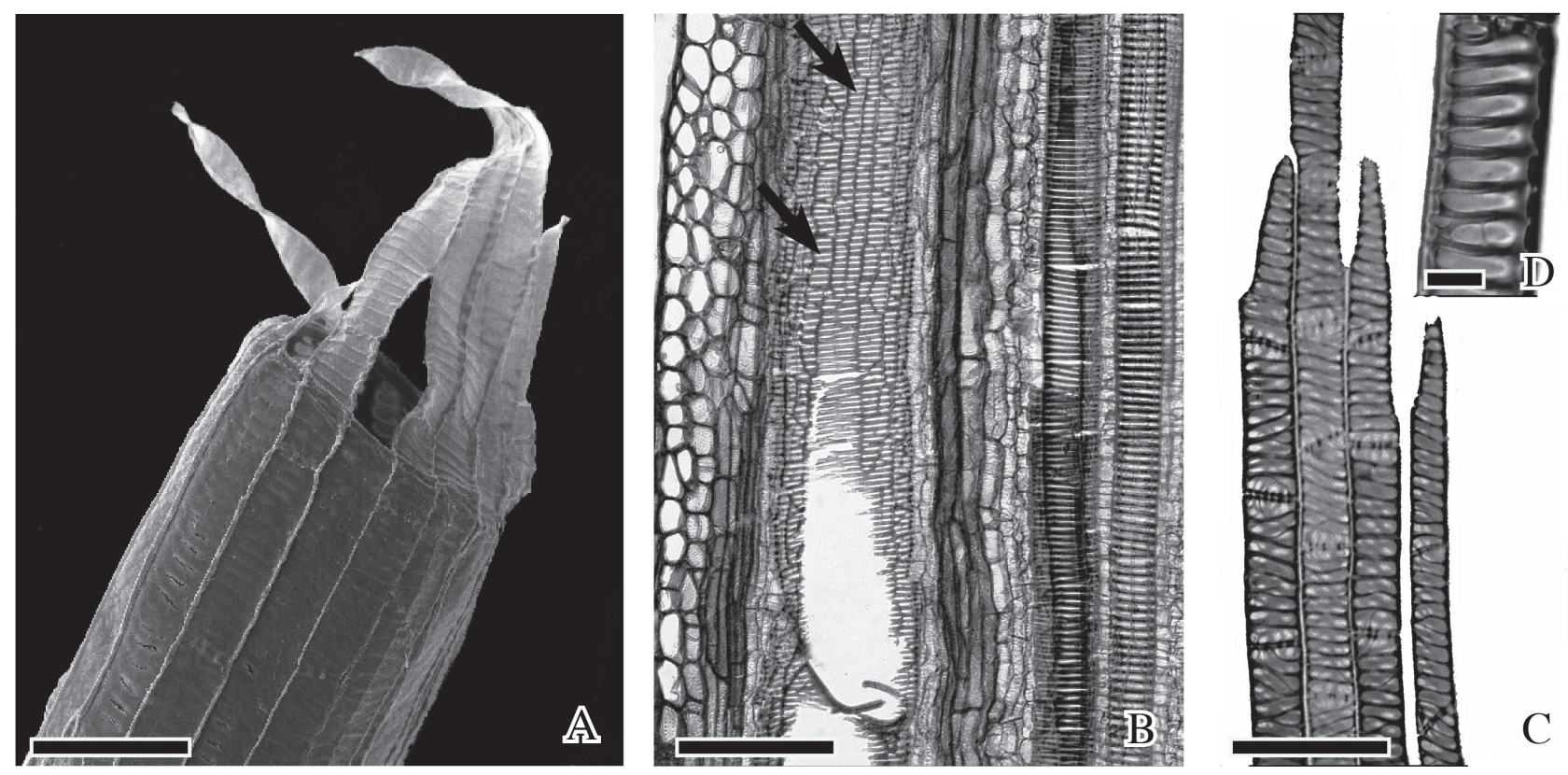

Figure 3. Paratracheal contact parenchyma tissue. A. Syagrus flexuosa (Mart.) Becc., SEM image showing parenchyma surrounding a vessel element with simple perforation plate. B. Syagrus romanzoffiana (Cham.) Glassman, longitudinal section (LS); note the marks of contact between the parenchyma with the vessel elements presenting large pits (arrows). C. Syagrus romanzoffiana (Cham.) Glassman, dissociated cells; paratracheal parenchyma cells are rectangular in shape, with large simple to semi-bordered scalariform pits. D. Syagrus romanzoffiana (Cham.) Glassman, detail of the contact parenchyma pits. Scale bars: $\mathrm{A}=60 \mu \mathrm{m}, \mathrm{B}=130$ $\mu \mathrm{m}, \mathrm{C}=70 \mu \mathrm{m}, \mathrm{D}=20 \mu \mathrm{m}$. 
sure potential may be one of the most important means of avoiding the formation of gas embolism in palm stems ( $\mathrm{Da}$ vis 1961), with the probable involvement of high pressure potentials in embolism repair during either the wet season, after prolonged rain, or during the night. Another system that could aid in refilling vessels post-embolism is the presence of paratracheal parenchyma closely associated with the vessels (Braun 1984), as found in the three Syagrus species studied. Indeed, it has been suggested that vessel-associated cells could create a positive osmotic gradient between the parenchyma cells and the vessel elements, intermediated by the plasma membrane of the contact parenchyma cells, so that these parenchyma cells could regenerate water flux in previously embolized vessels (Czaninski 1968; 1977; Sauter 1981; Braun 1984).

Besides the phenomenon of high root pressure potentials, the presence of leaf to stem hydraulic constrictions in palms is thought to be another efficient mechanism to avoid stem vessel embolism (Sperry 1985), showing that palms possess complex mechanisms to avoid stem damage. Hydraulic constrictions are specific regions between the stem and leaves where only protoxylem is present. Under these conditions, the vessels in the leaves would be more susceptible to embolism, but the vessels in the stems more protected (Sperry 1985). The presence of long, narrow and multi-perforated plates in the vessel elements of the leaves is another mechanism that helps in embolism repair (Sperry 2003).

In addition to very long root vessel elements, we identified differences in the lengths among the vessel elements of closely related taxa growing in similar environments, a phenomenon which had never been recorded. In the aerial stem of Syagrus romanzoffiana, the stem vessels were as long as those in the roots and leaves. In Syagrus flexuosa, on the other hand, stem vessels were found to be shorter than those in the roots and leaves. Finally, in Syagrus petraea, the stem vessels were more than three times shorter than the vessels of roots and leaves. We cannot explain why the vessels in Syagrus romanzoffiana would all possess the same length. For Syagrus flexuosa, the presence of vessels in the stem, which are shorter than those in leaves, agrees with what is expected for Monocotyledons as a whole (Cheadle 1942). However, the presence of very short vessels in Syagrus petraea, which is totally dissimilar to the vessels found elsewhere in the plant, may indicate the functional specificity of this subterranean organ. Studies with other storage and succulent organs, such as rhizomes, obtained similar results, with either the absence of vessels (Carlquist \& Schneider 2007) or the presence of minute, less specialized vessels (Carlquist 1975; Carlquist \& Schneider 2006; 2007). Such storage organs are thought to possess very low water flow rates and act primarily as water storage organs (Carlquist \& Schneider 2007).

In terms of width and type of perforation plates across distinct plant organs, we can conclude that the vessel elements of Syagrus palms share the same types of variation with all Monocotyledons. However, based on the anatomical results of our study, these palms also present a previously unknown variation in the lengths of vessels elements, most likely related to both growth habit and organ function, as we have demonstrated. Therefore, the present study provides evidence that the differences found among the vessel elements of roots, stem and leaves of the Monocotyledons may have evolved in response not only to environmental and ecological constraints, but also the growth habit and function of the organs within the plant.

\section{Acknowledgements}

The authors thank Antonio Carlos Franco Barbosa (Institute for Technological Research of São Paulo) for help with anatomical procedures, and Amauri Marcato and Milton Groppo for collecting and identifying the palms studied. Financial support was granted by the São Paulo Research Foundation (grant 00/08182-0) and the National Council for Scientific and Technological Development (grant 3088893/2006-9).

\section{References}

APG III. 2009. An update of the Angiosperm Phylogeny Group classification for the orders and families of flowering plants: APG III. Botanical Journal of the Linnean Society 161: 105-121.

Baas, P.; Werker, E. \& Fahn, A. 1983. Some ecological trends in vessel characters. IAWA Bulletin n.s. 4: 141-159.

Bailey, I.W. 1944. The development of vessels in Angiosperms and its significance in morphological research. American Journal of Botany 31(7): 421-428.

Bailey, I.W. \& Tupper W.W. 1918. Size variation in tracheary cells. I. A comparison between the secondary xylems of vascular cryptogams, gymnosperms and angiosperms. Proceedings of the American Academy of Arts and Sciences 54(1-4): 149-204.

Barbosa, A.C.F.; Pace, M.R.P; Witovsk, L. \& Angyalossy, V. 2010. A new method to obtain good anatomical slides of heterogeneous plant parts. IAWA Journal 31(4): 373-383.

Berlyn, G.P. \& Miksche J.P. 1976. Botanical microtechnique and cytochemistry. Ames, The IOWA StatePress.

Braun, H.J. 1984. The significance of the accessory tissues of the hydrosystem for osmotic water shifting as the secondary principle of water ascent, with some thoughts concerning the evolution of trees. IAWA Bulletin n.s. 5: 275-294.

Bukatsch, F. 1972. Bemerkungen zur Doppelfärbung Astrablau-Safranin. Microkosmos 61: 255 .

Canny, M.J. 2001. Embolism and refilling in the maize leaf lamina, and the role of the protoxylem lacuna. American Journal of Botany 88(1): 47-51.

Carlquist, S. 1975. Ecological strategies of xylem evolution. Berkeley, University of California Press.

Carlquist, S. 1982. The use of ethylenediamine in softening hard plant structures for paraffin sectioning. Stain Technology 57(5): 311-317.

Carlquist, S. \& Schneider E.L. 1997. Origins and nature of vessels in monocotyledons .1. Acorus. International Journal of Plant Sciences 158(1): 51-56.

Carlquist, S. \& Schneider E.L. 1998a. Origins and nature of vessels in monocotyledons. 3. Lowiaceae, with comments on rhizome anatomy. Blumea 43(1): 219-224. 
Carlquist, S. \& Schneider E.L. 1998b. Origin and nature of vessels in monocotyledons. 5. Araceae subfamily Colocasioideae. Botanical Journal of the Linnean Society 128(1): 71-86.

Carlquist, S. \& Schneider E.L. 2001. Vessels in ferns: structural, ecological, and evolutionary significance. American Journal of Botany 88(1): 1-13.

Carlquist, S. \& Schneider E.L. 2002. The tracheid-vessel element transition in angiosperms involves multiple independent features: cladistic consequences. American Journal of Botany 89(2): 185-195.

Carlquist, S. \& Schneider E.L. 2006. Origins and nature of vessels in monocotyledons: 8. Orchidaceae. American Journal of Botany 93(7): 963-971.

Carlquist, S. \& Schneider E.L. 2007. Origins and nature of vessels in monocotyledons. 9. Sansevieria. South African Journal of Botany 73(2): 196-203.

Cheadle, V.I. 1942. The occurrence and types of vessels in the various organs of the plant in the Monocotyledoneae. American Journal of Botany 29(6): 441-450.

Cheadle, V.I. 1943a. The origin and certain trends of specialization of the vessel in the Monocotyledoneae. American Journal of Botany 30(1): 11-17.

Cheadle, V.I. 1943b. Vessel specialization in the late metaxylem of the various organs in the Monocotyledoneae. American Journal of Botany 30(7): 484-490.

Cheadle, V.I. 1944. Specialization of vessels within the xylem of each organ in the Monocotyledoneae. American Journal of Botany 31(2): 81-92.

Cheadle, V.I. 1953. Independent origin of vessels in the Monocotyledons and Dicotyledons. Phytomorphology 3: 23-44.

Cheadle, V.I. 1955. The taxonomic use of specialization of vessels in the metaxylem of Gramineae, Cyperaceae, Juncaceae, and Restionaceae. Journal of the Arnold Arboretum 36: 141-158.

Cheadle, V. I. \& Whitford N.B. 1941. A discussion of some factors which influence the form of vascular bundle in the Monocotyledoneae. American Journal of Botany 28(Supplement): 2s.

Cheadle, V.I. \& Kosakai H. 1975. Vessels in Juncales: II. Centrolepidaceae and Restionaceae. American Journal of Botany 62(10): 1017-1026.

Czaninski, Y. 1968. Étude du parenchyma ligneux du Robinier (parenchyma à reserves et cellules associées aux vaisseaux) au cours du cycle annuel. Journal Microscopie 7: 145-164.

Czaninski, Y. 1977. Vessel-associated cells. IAWA Bulletin 3: 51-55.

Davis, T.A. 1961. High root-pressures in palms. Nature 192: 277-278.

Dransfield, J.; Uhl; N.W.; Asmussen, C.B.; Baker, W.J.; Harley, M.M. \& Lewis C.E. 2005. A new phylogenetic classification of the palm family, Arecaceae. Kew Bulletin 60: 559-569.

Eckblad, J.W. 1991. How many samples should be taken? BioScience 41: 346-348.

Fisher, J.B.; Tan, H.T.W. \& Toh L.P.L. 2002. Xylem of Rattans: vessel dimensions in climbing palms. American Journal of Botany 89(2): 196-202.

Franklin, L. 1945. Preparation of thin sections of synthetic resin and wood. Resin composites, and a new macerating method for wood. Nature 155: 51.
Frost, F.H. 1930a. Specialization in secondary xylem of dicotyledons. I. Origin of vessel. Botanical Gazette 89: 67-94.

Frost, F.H. 1930b. Specialization in secondary xylem of dicotyledons. II. Evolution of end wall of vessel segment. Botanical Gazette 90 198-212.

Klotz, L.H. 1978a. Observations on diameters of vessels in stems of palms. Principes 22(3): 99-106.

Klotz, L.H. 1978b. Form of the perforation plates in the wide vessels of metaxylem in palms. Journal of the Arnold Arboretum 59(2): 105-128.

Maherali, H.; Pockman, W.T. \& Jackson, R.B. 2004. Adaptive variation in the vulnerability of woody plants to xylem cavitation. Ecology 85(8): 2184-2199.

Parthasarathy, M.V. \& Klotz L. H. 1976. Palm “wood” I. Anatomical aspects. Wood Science and Technology 10: 215-229.

Rupp, P. 1964. Polyglykol als Einbettungsmedium zum Schneiden botanischer Präparate. Mikrokosmos 53: 123-128.

Sauter, J.J. 1981. Sucrose uptake in the xylem of Populus. Zeitschrift für Pflanzenphysiologie 103: 105-168.

Schneider, E.L. \& Carlquist S. 1995. Vessel origins in Nymphaeaceae: Euryale and Victoria. Botanical Journal of the Linnean Society 119(3): 185-193.

Schneider, E.L. \& Carlquist S. 1996. Vessels in Brasenia (Cabombaceae): New perspectives on vessel origin in primary xylem of angiosperms. American Journal of Botany 83(9): 1236-1240.

Schneider, E.L. \& Carlquist S. 1997. Origins and nature of vessels in monocotyledons .2. Juncaginaceae and Scheuchzeriaceae. Nordic Journal of Botany 17(4): 397-401.

Schneider, E.L. \& Carlquist S. 1998. Origin and nature of vessels in monocotyledons. 4. Araceae subfamily Philodendroideae. Journal of the Torrey Botanical Society 125(4): 253-260.

Schneider, E.L. \& Carlquist S. 2000a. SEM studies on vessels of the homophyllous species of Selaginella. International Journal of Plant Sciences 161(6): 967-974.

Schneider, E.L. \& Carlquist S. 2000b. SEM studies on the vessels of heterophyllous species of Selaginella. Journal of the Torrey Botanical Society 127(4): 263-270.

Schneider, E.L. \& Carlquist S. 2005. Origin and nature of vessels in Monocotyledons. 7. Philydraceae and Haemodoraceae. Journal of the Torrey Botanical Society 132(3): 377-383.

Sperry, J.S. 1985. Xylem embolism in the palm Rhapis excelsa. IAWA Bulletin n.s. 6(4): 283-292.

Sperry, J.S. 2003. Evolution of water transport and xylem structure. International Journal of Plant Sciences 164(3 Supplement): 115-S127.

Sperry, J.S.; Hacke, U.G.; Feild, T.S.; Sano, Y. \& Sikkema, E.H. 2007. Hydraulic consequences of vessel evolution in angiosperms. International Journal of Plant Sciences 168(8): 1127-1139.

Tomlinson, P.B.; Fisher, J.B.; Spangler, R.E. \& Richer R.A. 2001. Stem vascular architecture in the Rattan palm Calamus (ArecaceaeCalamoideae-Calaminae). American Journal of Botany 88(5): 797-809. 